\section{Origem e destino revisitados: a clonagem entre a profecia e a promessa}

\author{
Origin and destiny \\ revisited: cloning as \\ prophecy and promise
}

Ana Maria Coutinho Aleksandrowicz

Doutora em Ciências (Saúde Pública) da Escola Nacional de Saúde Pública/Fiocruz Rua do Catete, 311 sala 1305 22220-001 - Rio de Janeiro - RJ - Brasil analeks@unisys.com.br

Fermin Roland Schramm

Pesquisador titular em Ética Aplicada e Bioética da Escola Nacional de Saúde Pública/Fiocruz Rua Leopoldo Bulhões, 1480 - sala 914 21041-210 Rio de Janeiro - RJ - Brasil roland@ensp.fioccruz.br
ALEKSANDROWICZ, Ana Maria Coutinho; SCHRAMM, Fermin Roland. Origem e destino revisitados: a clonagem entre a profecia e a promessa. História, Ciências, Saúde-Manguinhos, Rio de Janeiro, v.14, n.2, p.421-441, abr.-jun. 2007.

Este artigo apresenta as posições sobre a clonagem do biofísico e filósofo espinosista Henri Atlan, descritas nos diferentes registros das 'racionalidades científica e mítica' categorias estruturantes do pensamento desse autor, nas fronteiras entre ciências naturais, ciências humanas e ética. Se, do primeiro ponto de vista, a clonagem, uma vez circunscrita a suas possibilidades efetivas de ocorrência, prenuncia aplicações propícias à saúde e ao bem-estar humanos, é sob a égide do segundo que surgem interpretações simbólicas dúbias e, freqüentemente, assustadoras. Além de expor a gênese mítica desses equívocos, Atlan - em conformidade com sua linhagem não-dicotômica e otimista espinosista - posiciona-se a favor do progresso científico ao qual seria paralelo o aumento da condição humana de compreensão mais ampla de sua 'origem e destino'.

PALAVRAS-CHAVE: clonagem; ciência; mito; filosofia da biologia; qualidade de vida.

ALEKSANDROWICZ, Ana Maria Coutinho; SCHRAMM, Fermin Roland. Origin and destiny revisited: cloning as prophecy and promise. História, Ciências, Saúde Manguinhos, Rio de Janeiro, v.14, n.2, p.421-441, Apr.-June 2007.

This article sets out the positions held on cloning by the contemporary French Spinozist philosopher and biophysicist, Henri Atlan, described in the different records of Atlan's "scientific and mythical rationales", which are categories that structure the thinking of this author, crossing boundaries between the natural, human and social sciences and ethics. Having set out the actual possibility of cloning taking place, if from the first perspective one can initially foretell applications that will foster human health and welfare, it is from the second that ambivalent and often alarming symbolic interpretations may arise. Not only does Atlan expose the mythical origins of these mistaken ideas, but, in line with his non-dichotomical and Spinozist lineage, he takes a stance in favor of scientific progress, which is paralleled by an expanded human propensity to comprehend more broadly their "origins and destiny".

KEYWORDS: cloning; science; myth; philosophy and biology; quality of life. 
E à mulher disse: "Multiplicarei sobremodo os sofrimentos de tua gravidez; em meio de dores darás à luz filhos; o teu desejo será para o teu marido e ele te governará".

E a Adão disse: "Visto que atendeste a voz de tua mulher e comeste da árvore que eu ordenara não comesses; maldita é a terra. Por tua causa: em fadigas obterás dela o sustento durante os dias de tua vida".

Bíblia, Velho Testamento, Gênesis, III:16-19

Por isso vos digo: pedi e dar-se-vos-á; buscai e achareis; batei e abrir-se-vos-á.

Pois todo o que pede, recebe; o que busca, encontra; e a quem bate, abrir-se-lhe-á.

Bíblia, Novo Testamento, Lucas, XI:9-10

$\mathrm{N}$ este trabalho, a candente questão da clonagem será aborda da tendo como referencial constante as idéias de Henri Atlan, que serão associadas a pontos de vista convergentes, sempre nas delicadas fronteiras entre a ciência e o mito, área de tensão privilegiada para a discussão do tema. Nesse sentido, a Weltanschauung que norteia nossa reflexão afina-se com a defesa da clonagem como estratégia terapêutica e proposta filosófica. Contudo, manteremos presente a necessidade imprescindível de uma adequada repercussão, em searas éticas, dos reais alcances e objetivos da clonagem. Nosso fio condutor neste trajeto será, pois, a explicitação de quão promissoras, em termos de bem-estar e felicidade humanos, podem vir a ser as perspectivas oferecidas pela clonagem, a par do esclarecimento do conteúdo mítico supersticioso ('profético') que assombra esses mesmos horizontes.

Num primeiro momento, após a revisão dos constructos das 'racionalidades científica e mítica' atlanianas, alinhavaremos os argumentos de teor científico, sublinhando os equívocos - no mesmo diapasão da utilização inadequada da metáfora do 'programa genético' (Atlan, 1979; 1999c) - quanto ao correto entendimento dos termos científicos e técnicos em questão, que levam a se creditar à clonagem uma importância exagerada (de ordem mítica) na manipulação do 'destino' humano. Acresce-se que a própria compreensão, desnuda de preconceitos, dos limites pragmáticos (categoria inalienável da racionalidade tecnocientífica) da clonagem restringe seu real alcance. Num segundo momento, já no registro da racionalidade mítica, acompanharemos a interpretação atlaniana das vicissitudes que envolvem a díade criador-criatura como mitos de origem fundadores do Ocidente. Ressaltaremos a conotação negativa impressa às relações entre criador e criatura nas narrativas míticas desde o advento da Modernidade, tendência que se exacerba quando se problematiza, atualmente, o assim chamado 'pós- 
humano' . Num terceiro momento, em busca da conciliação entre ciência e ética, encamparemos a tese atlaniana de que a clonagem insere-se numa proposta, em molde evolutivo, de libertação biológica e simbólica de homens e mulheres, compreendidos como seres necessariamente impulsionados por sua vocação ao progresso e à autonomia. A base epistemológica desse projeto é, para Atlan (1999a), a aliança da continuação do projeto iluminista pós-kantiano com uma releitura de Espinosa que recusa a dicotomia cartesiana, de maneira a aproximar, sem misturá-los, os estatutos das ciências naturais e da ética. A partir daí, Atlan (1999a; 2003; 2005) pode advogar a superação dos obstáculos concretos e simbólicos à plenitude da experiência existencial do ser humano em todos os seus níveis de manifestação (molecular, biológico, fisiológico, emocional, social e filosófico) - satisfazendo, assim, os imperativos éticos espinosistas, que entrelaçam conhecimento e felicidade.

\section{Possibilidades biológicas extensas e impossibilidades sociais provisórias}

A clonagem é abordada de maneira sistemática por Henri Atlan, em sua qualidade prioritária de cientista (formado, substancial mente, na filosofia espinosista), em Le clonage humain (Atlan, 1999b), obra em conjunto com um antropólogo, uma jurista, um filósofo especializado no pensamento oriental e uma historiadora. Sentimonos à vontade para fazer dessa referência nosso fio condutor, uma vez que os dados ali apresentados não só se mantêm substancialmente atuais como conhecimento ainda não refutado, como se coadunam perfeitamente com outros avanços recentes das biotecnologias, como aqueles referentes ao útero artificial (Atlan, 2005).

O próprio título do capítulo escrito por Atlan no livro de 1999, que inicia a discussão, é "Possibilidades biológicas, impossibilidades sociais". Os adjetivos que acrescentamos - 'extensas' e 'provisórias' - acentuam o real teor de suas restrições circunstanciais à clonagem. Com efeito, Atlan enfatiza não haver razões metafísicas ou qualquer ponto de vista de tipo essencialista - pois a natureza humana não é algo dado de uma vez por todas, mas se modifica ininterruptamente - que justifiquem interditar a clonagem. Tampouco dever-se-ia, segundo Atlan, recear o avanço das pesquisas, que, pelo menos atualmente, têm em suas dificuldades intrínsecas um limitador à sua proclamada capacidade de causar danos irreversíveis ao ser humano. O motivo da cautela atlaniana - restrita ao presente momento mental e cultural - é o uso mítico inadequado da clonagem, que poderia afetar os indivíduos clonados (no caso da clonagem reprodutiva), pois, considerada a especificidade das condições em que foram gerados, os clones correriam o risco de ser objeto de fantasias e preconceitos penosos. Tal situação tende- 
ria a provocar sofrimentos psíquicos e sociais superiores aos possíveis ganhos biológicos e fisiológicos provenientes da superação das limitações atuais.

Subjacente à tese atlaniana está a postulação de duas formas de racionalidade - a científica e a mítica - que permeariam entendimentos e ações humanas. Para Atlan, a racionalidade científica é reconhecível segundo os critérios vigentes de raciocínio operacional, endossados pela lógica e pela ciência, isto é, pelo tipo de racionalidade que "caminhando do particular para o geral [é] limitada pelas condições impostas pela aplicação de rigorosos métodos de que se faz rodear, a objetos que lhe são adaptados e, por essa razão, cuidadosamente circunscritos e definidos" (Atlan, 1986, p.10). Vincula-se ao discurso científico que "pretende ser um discurso sem sombras, transparente e unívoco, [que] transforma [as coisas] em quantificadores lógicos e em operadores" (Atlan, 1991, p.9). Por sua vez, a racionalidade mítica é aquela "que dá um sentido às coisas ... preservando o caráter único de cada experiência” (Atlan, 1986, p.20) e "o caráter central e obrigatório da intuição primeira de nosso corpo, de nosso meio biológico e social" (Atlan, 1991, p.15). Pertencem a este segundo tipo o próprio mito e a arte, expressões do inconsciente; a mística; a metafísica; e algumas das "questões ... pormenorizadamente analisadas ao longo de séculos de atividade filosófica" (Atlan, 1986, p.13), como a finalidade e o animismo.

Segundo Atlan, as duas formas de racionalidade são igualmente importantes, aplicando-se, no entanto, a domínios diferentes da experiência humana. É necessário, pois, delimitar as áreas de pertinência das conclusões a que se chega através do exercício de cada uma. Nesse sentido, podemos aproximar alguns pressupostos atlanianos daquele da assim chamada 'lei de Hume', que, ao discernir entre fatos e valores, proíbe efetuar a passagem 'do ser ao deverser', isto é, do descritivo ao prescritivo; em suma, inferir normas de condutas com base em situações factuais, recomendando distinção entre questões epistemológicas (que incluem as científicas) e questões éticas, para evitar paralogismos ou aquilo que Moore (1998) identificou como 'falácia naturalística' (naturalistic fallacy). À medida que se dedica à filosofia espinosista, Atlan aproxima a racionalidade mítica à imaginação (primeiro gênero de conhecimento na Ética) e a racionalidade científica à razão (segundo gênero de conhecimento). Assim como se refere à intuição como o terceiro gênero de conhecimento (Ética II; prop. XL; esc. II), imprescindível para acesso à sabedoria, também para Atlan é preciso que o ser humano desenvolva essa via que, distinguindo entre os imperativos da imaginação (ou seja, de um repertório mítico individual e ou social) e aqueles da razão (ou seja, das conclusões verdadeiras no âmbito das conquistas científicas), atende a uns e outros no sentido de aprimorar sua qualidade de vida (Aleksandrowicz, 2002). 
Segundo Atlan, toda proposição relevante para o existir humano passa, pois, por essa dupla decodificação. Alguns assuntos que, do seu ponto de vista técnico-operacional, são da alçada das ciências adquirem uma repercussão mítica extraordinária, porque lidam com problemas cruciais para essa área da experiência humana. Entre eles, as especulações sobre a origem e o destino de homens e mulheres, vazadas naquelas sobre o mistério da criação, em que criador e criatura imemorialmente, nas tradições religiosas, disputam o cetro das decisões sobre os inícios e os fins. Toda uma amplíssima gama de temas permeia essa particular instância mítica, norteada pela preocupação com a permanência e/ou integridade, a sobrevivência e/ou transcendência do ser, assim como com a sexualidade e com a filiação.

Assim, é no terreno das indagações míticas que viceja a ética (Atlan, 1986; 2002), pois é nessa esfera que indivíduos e grupos sociais procuram respostas significativas para suas inquietações. Vinculando-se a uma orientação iluminista, reativada pela aliança com a inspiração espinosista, Atlan acredita numa superação gradual da superstição (no sentido espinosista do termo), uma vez que esta se constitui numa expressão da racionalidade mítica dissociada de sua potencialidade de conduzir à sabedoria. Todavia o mito, se compreendido e vivenciado em seu alcance mais profundo, pode encarnar e impulsionar esse movimento. Atlan (1999a; 2003) explora tais dimensões baseado numa leitura muito particular dos mitos judaicos, aos quais, por vezes, justapõe mitos gregos - uma vez que, a exemplo de estudiosos como Colli (1975), defende a continuidade entre o pensamento mítico e a filosofia. Reinterpretando o modelo espinosista, Atlan (1999a; 2003) argumenta que também o homem em busca da sabedoria, em suas escolhas éticas, utiliza o seu próprio referencial mítico (primeiro gênero de conhecimento). Ele o faz, todavia, informado por seus limites pela ciência (segundo gênero de conhecimento) e por uma compreensão filosófica visceral (terceiro gênero de conhecimento) do papel de um determinismo impessoal, atuante nas apreensões da realidade que condicionam suas opções.

Isso posto, verifica-se por que um trabalho sobre ética e clonagem norteado pela elaboração atlaniana, após a explicitação da pertinência da investigação científica e das possibilidades que delineiam para melhoria da qualidade de vida do ser humano, detémse na busca de compreensão das repercussões míticas das conquistas científicas. Neste texto distinguiremos o que chamamos de 'profecias', nas quais fantasias catastróficas estariam sendo projetadas para o futuro, de 'promessas', cuja expectativa simbólica é a promoção de melhor qualidade de vida para os futuros beneficiários das técnicas em desenvolvimento. Nesse sentido, solidarizamo-nos com a oposição atlaniana ao 'princípio de prudência', pois “[a] pru- 
dência não é um princípio. É uma virtude que acompanha a ação, tão difícil de quantificar quanto a inteligência e o bom senso. Seu exercício é uma arte difícil que se refere à intuição e à inteligência das situações, inclusive ao hábito da sabedoria" (Atlan, 2003, p.90).

No aspecto estritamente médico-biológico, as proposições atlanianas parecem afinar-se com aquelas segundo as quais "a clonagem terapêutica e a clonagem reprodutiva visam responder ao desafio do sofrimento humano desnecessário ... tendo em vista uma melhor qualidade de vida" (Schramm, 2003a, p.187), considerando que "não existem, atualmente, argumentos substanciais para aceitar a distinção entre clonagem terapêutica e clonagem reprodutiva, nem para aceitar a primeira e não a segunda, a não ser a necessária [virtude da] prudência até que ambas se tornem razoavelmente seguras e eficientes" (p.194). Entretanto, no momento presente, Atlan se declara contra a clonagem reprodutiva, que é ainda mal assimilada culturalmente. Trata-se de posição provisória, até que a racionalidade mítica se revele significativamente mais permeável à 'promessa' (na qual, segundo seu mito arquetípico prometéico, a técnica serve ao homem) do que à 'profecia' (segundo a qual, a técnica sujeitar-se-ia à imposição do arbítrio inclemente do criador à criatura e ou às suas vicissitudes) - no sentido em que estamos empregando tais termos neste artigo.

Considerado o projeto de esclarecimento atlaniano, uma vez que a clonagem terapêutica pode ser reconhecida como prioritariamente benéfica, sua explanação centra-se em explicitar os reais contornos da clonagem reprodutiva, reputada como a grande ameaça à 'indeterminação' do destino genético humano. Em seu livro de 1999 (Atlan, 1999b) - nossa principal fonte de referência neste tópico - o autor detalha cientificamente o processo e retifica equívocos. Distingue técnicas como a cisão de embriões (por meio da qual o embrião é gerado pela reprodução sexual habitual) e a clonagem reprodutiva (em que o embrião é gerado de forma assexuada, sem fusão de gametas ou recombinação dos genes dos pais), desarticulando a ilusão de que a clonagem reprodutiva corresponderia automaticamente à produção de inúmeros indivíduos geneticamente idênticos entre si. Acrescente-se que, embora nada impeça a combinação das duas técnicas, a dificuldade inerente à boa execução de cada uma delas, em termos práticos, afasta ainda muito essa perspectiva. Porém nem toda transferência de núcleo constituiria uma clonagem, caracterizando muitas fecundações in vitro em que há a fecundação de um óvulo por um espermatozóide, fusão de gametas e constituição de um novo genoma.

Mas, consoante a sua vocação científica, o golpe de mestre facultado pela clonagem, para Atlan, em oposição ao que o senso comum fantasia, é que sua compreensão adequada ajuda a levar adiante a refutação da metáfora do 'programa genético'. Esse é o pro- 
jeto atlaniano desenvolvido desde 1979 e cada vez mais rigorosamente definido (Atlan, mai-juin 1995; 1996; 1999c), posto que a orientação 'proteômica', à qual ele se vincula, passa a ser a linha de pesquisa predominante em biologia molecular. Assim, o grande interesse científico das experiências de transferência do núcleo celular para um animal é porque elas permitem estudar o papel respectivo do núcleo - contendo o genoma do embrião - e do citoplasma, de origem materna, do óvulo. Admitia-se existir aqui uma impossibilidade de princípio, pois o desenvolvimento embrionário seria determinado por um ' programa' inteiramente contido no genoma nuclear do embrião. À medida que as células se dividem e diferenciam para produzir os diferentes órgãos dos adultos, a atividade de seus genes seria modificada por esse 'programa' de desenvolvimento de forma irreversível. Cada tipo de célula seria resultado de um 'engajamento' (engagement) das células embrionárias, produzido segundo uma forma de diferenciação em que apenas uma parte do genoma do indivíduo está ativa, sendo produto das células desse tecido ou órgão e não de outro.

Ao contrário, a reprodução da ovelha Dolly, bem como das que se seguiram a ela, apresentou a prova experimental de que a diferenciação não é irreversível e depende, em parte, de fatores não-genéticos ligados às propriedades do citoplasma, portanto à ação das mitocôndrias. Descobriu-se que o genoma de uma célula adulta comporta-se como o de uma célula embrionária inicial: ele encontra todas as suas potencialidades para produzir os diferentes órgãos de um organismo adulto, com a condição de ser implantado no citoplasma de um óvulo. A partir de então, pode-se dizer que o genoma, que havia sido previamente diferenciado e cuja atividade se limitara à célula de um órgão ou tecido particular, é 'reprogramado' pelo citoplasma do óvulo, que não contém genes. Constatou-se que as proteínas do citoplasma desempenham um papel determinante na atividade desse programa de desenvolvimento, não somente no estado inicial do ovo fecundado, mas ao longo de toda a sua diferenciação embrionária. Assim, contrariamente ao que se acreditou durante muito tempo, o organismo controlaria a atividade do genoma tanto quanto o genoma controla o desenvolvimento e a atividade do organismo. É esta a razão por que as experiências de clonagem reprodutiva por transferência de núcleo são muito importantes para compreender a dinâmica de interações complexas entre determinações genéticas e epigenéticas no desenvolvimento embrionário.

Observe-se que a oposição atlaniana ao 'programa genético' é referente à sua fragilidade como metáfora para o determinismo absoluto da natureza, e não para o determinismo em si mesmo. Atlan discorda do projeto de descoberta de toda a determinação biológica de um indivíduo através do mapeamento de seus ADNs (que reputa 
cientificamente simplista, - em registro paralelo ao da confusão entre 'código' e 'programa' genéticos, e, além do mais, a serviço de propósitos de feição mítica questionáveis), assim como da asseveração de que todos os seus determinismos constituintes seriam biológicos, sendo esquecidos aqueles psíquicos e sociais. Todavia, não é impossível, a longo prazo, o conhecimento de todos os determinismos, inclusive os epigenéticos, uma vez que, para Atlan - na trilha de Espinosa -, a concepção de Acaso corresponde à de Ignorância (no sentido 'maiúsculo' desses termos). Essa ainda longínqua possibilidade dependeria, intrinsecamente, do desenvolvimento, no ser humano, de um senso de responsabilidade moral e não causal em relação a seus próprios determinismos, paralelo a uma evolução específica da consciência (Atlan, 1999a), conforme esboçaremos na terceira parte deste artigo.

Os argumentos que reforçam a importância dos fatores epigenéticos são decisivos para desmascarar o mito da similitude absoluta do ser clonado em relação ao ser que lhe deu origem - fonte de boa parte das objeções em termos identitários, uma vez que a face seria o elemento distintivo da pessoa - e, aqui, Atlan ecoa Levinas (1979), para quem a alteridade do outro é sempre da ordem do nãoassimilável ao mesmo, do mistério. Além de acentuar o conteúdo mítico distorcido dessa afirmação - que ignora o caráter interior distintivo da subjetividade, evidente em gêmeos, por exemplo -, Atlan lembra, com apoio nas evidências relacionadas ao desenvolvimento epigenético, que não há maiores indícios de que sequer existiria tal semelhança. Sem dúvida, ela é muito mais provável no caso de gêmeos univitelinos, que seriam mais 'clones' um do outro que os frutos da reprodução assexuada, representada pela clonagem reprodutiva, já que compartilham não só o material do núcleo como aquele do citoplasma. Mesmo esses, contudo, apesar da freqüente similitude de sua aparência física, apresentam variações entre si na estrutura das conexões nervosas de seus cérebros e naquela de seus sistemas imunológicos, resultando em expressões individuais biológicas distintas e, a fortiori, em expressões psicológicas diferentes, em virtude de experiências existenciais distintas.

Outrossim, Atlan ressalta as dificuldades técnicas inerentes à complexidade dos procedimentos de clonagem, nos quais se lida com uma multiplicidade exaustiva de variáveis. Alicerçado em dados pragmáticos, no mesmo diapasão que Schramm (2003a), prevê quão marginal deverá ser a utilização da clonagem reprodutiva. Por si mesmos, esses fatos anulam - como possibilidades efetivas de cunho científico, embora as superstições de cunho mítico aqui envolvidas possam persistir - os 'fantasmas totalitários' que assombram os debates em torno da clonagem. Por isso, também, não procedem os argumentos de que a variedade genética da população poderia diminuir, levando-se em conta, principalmente, que a 
transgenia poderia progredir a ponto de produzir variabilidade genética artificialmente, desde que a biotecnociência se tornasse suficientemente desenvolvida e controlada.

\section{Demônios e engrenagens: do Golem ao pós-humano}

Do ponto de vista biológico, está comprovado o continuum existente entre o ser vivo e o não-vivo, já em 1979 esmiuçado por Atlan. Paralelamente, controvérsias sobre os limites entre natural e artificial - ou entre o que foi e o que não foi alterado além de certa medida, na natureza, pelo engenho do homem - enfraquecem na mesma proporção em que diversas linhas de pesquisa, com ênfase naquelas em bioquímica e biofísica, apresentam inovações tecnológicas capazes de mitigar sofrimentos e deficiências humanos. Não há nenhum tipo de dissensão (a não ser da parte de religiões fundamentalistas ou em virtude do medo habitual diante do desconhecido) na aceitação de hibridismos decorrentes de clonagens terapêuticas. O desafio, ao contrário, nesses territórios pacificamente compartilhados é acelerar a conjunção do artificial e do natural. Sangue em pó, pele artificial e coração de titânio já estão disponíveis. O grande obstáculo é descobrir um meio pelo qual órgãos e tecidos artificiais sejam incorporados ao organismo plena e definitivamente. Com essa intenção, estão sendo criadas estruturas materiais que interagem com o organismo, como a pele artificial - com base no colágeno bovino - e a de silicone (Neiva, 2003).

A polêmica permanece acesa nos redutos simbólicos em que a questão do destino da humanidade (e de cada indivíduo) está ligada à sua origem: paradoxalmente, privilegiada (por sua condição de acesso ao conhecimento) e ao mesmo tempo condenada (porque se adquire indevidamente esse conhecimento, pecado original), segundo os desígnios de um criador onipotente. Contra este, a criatura se revolta incessantemente, deixando-se subjugar e punir para, mais adiante, voltar a se rebelar.

Os mitos fundadores nos quais Atlan se concentra para ilustrar e problematizar a condição humana são os bíblicos de criação e passagem, principalmente o das árvores da vida e do conhecimento, e os de episódios similares posteriores. Esses descrevem as consecutivas quedas do homem e sua conseqüente entrega a ilusões para envidar - magicamente - o retorno a um paraíso em si mesmo ambíguo. Protótipos dessas ilusões são 'as faíscas de acaso' ('les étincelles de hasard'), nome que a tradição judaica dá às gotas de esperma espalhadas por Adão após sua expulsão do paraíso, quando ele e Eva permaneceram separados por 130 anos. Delas teriam nascido demônios enganadores que, por sua vez, originaram as gerações 'perdidas' (em relação ao conhecimento) do Dilúvio e da Torre de Babel. 
Em sua tradução literal, 'a árvore do conhecimento bom e mau' é também a 'da vida e da morte misturadas'. Entretanto, a árvore da vida estaria 'escondida', só se revelando no momento em que Adão se apropriasse do conhecimento do bem e do mal. Conforme o uso que fizesse deste, em termos de sabedoria, ele poderia obter a imortalidade. Como Adão falhou na prova proposta por Deus, forjou-se "a ambivalência constitutiva do conhecimento", que é ao mesmo tempo bom e mau, "portador da vida e da morte, fonte de verdade e de ilusão" (Atlan, 1999a, p.20).

Porém, aos demônios gerados pelas 'faíscas de acaso' atribuiu-se uma causalidade eficaz nos acontecimentos naturais fortuitos que os humanos tomam por maléficos ou benéficos. Atlan (1999a, p.179) os associa a determinado uso de explicações para dar inteligibilidade ao mundo, entendendo que "a explicação pelas 'causas ocultas' caracteriza tanto o pensamento mágico quanto o conhecimento científico". O tipo de conhecimento oferecido pelos demônios não é adequado para satisfazer a ambição humana de vencer o jugo do destino, conforme comprovam os episódios do Dilúvio e da Torre de Babel-em que, empenhados nesse objetivo, os homens acabam por se perder. O motivo de sua ruína teria sido a procura canhestra do conhecimento por meio de, respectivamente, fusão no todo indiferenciado ou fechamento em linguagens entendidas apenas pelos seus emitentes (Atlan, 1999a). Nesses cenários, a incipiente tecnologia instala-se logo como mediadora passível de manipulações mágicas.

Assim, enquanto houver criador e criatura, conforme o significado convencional desses termos na leitura corriqueira dos mitos fundadores da civilização judaico-cristã, a profecia que condena a raça humana continuará válida. Certa compreensão que o homem faz da criação, embebida na dialética hierárquica entre criador e criatura, instauraria determinadas percepções (míticas) da natureza dessas relações, sempre tensas e opositivas. Nesse quadro específico de referências, a tecnologia - tal como entendemos este termo desde a Modernidade - em lugar de ser decodificada (como fará a racionalidade científica), como instrumento neutro de mensurações e alterações de dados e fatos da realidade, insere-se imediatamente, segundo os códigos da racionalidade mítica em discussão, num contexto simbólico em que descobertas e invenções são entendidas como artefatos mágicos capazes de mimetizar e/ou inverter as condições originárias das relações de controle, conquista ou retaliação entre criador e criatura. Assim, o domínio da natureza propiciado pela tecnologia torna-se uma situação escorregadia, em que não se pode ter segurança, permitindo, como veremos adiante, que novas 'criaturas' se insurjam contra seus 'criadores'.

Prenunciando a Modernidade, nas searas da racionalidade mítica judaica surge o Golem, que é um homem artificial, construído por 
meio de mágica cabalística para servir a seu inventor, o que redunda sempre em problemas (Unterman, 1992). Seria justamente essa utilização indevida da criatura pelo criador que constituiria o entrave em razão do qual se repetem insubordinações, alternâncias de papéis e castigos. Dentro de simbólica similar, ilustrando-a pelo avesso, Atlan (Atlan, Bousquet, 1994) cita um Golem que teria sido fabricado pelo profeta bíblico Jeremias com tanta perfeição que chegava a falar. Dotado, ele também, de sabedoria, propôs a seu criador que o desfizesse, anulando dessa forma a antiga dicotomia.

$\mathrm{O}$ mesmo tema pode ser relido nas narrativas míticas recentes do Ocidente - principalmente as expressas em seu registro artístico - em que, com base na fabricação de autômatos semoventes, começa-se a questionar, no século XVII, até que ponto o simulacro mecânico do homem poderá substituir, em virtude de sua maior perfeição, o próprio inventor. Em inspirado ensaio, Moraes (2002) analisa as vicissitudes dessa tendência, uma vez que o crescente fascínio da época por essas engenhocas teria sido motivado por seu funcionamento aparentemente independente da intervenção (e do controle) humanos, a ponto de "a dúvida, em vez de incidir sobre a máquina que simula um ser vivo, acaba[r] por transformá-la no objeto a partir do qual a própria realidade humana é posta à prova" (p.96).

A interação do homem com seus simulacros tornou-se mais e mais agressiva e, no embate de racionalidades que se acentua nos dois últimos séculos, a figura do cientista identifica-se à do criador que manipula a criatura. No século XIX, Frankenstein (de Mary Shelley), feito de fragmentos de cadáver, volta-se contra seu inventor, um estudante de química. No século XX, em Metropolis (de Fritz Lang), é um cientista que cria um autômato, em forma feminina, para pregar aos operários uma violência destruidora. Também um cientista inventa os replicantes de Blade runner (de Ridley Scott) e é morto por suas ultrajadas criaturas. Em todos esses exemplos há uma relação desigual entre criador e criatura que pode ser assimilada à escravidão. Seria esse o substrato simbólico em que se encaixam os clones, na imaginação mítica hodierna, que substituem por seres humanos entre virtuais e reais aqueles personagens fictícios. Como Rouanet (2003) observa, há clara convergência dessas interpretações com as reflexões de Habermas (2001), para quem a clonagem equivaleria a uma verdadeira escravidão genética, por interferir num patrimônio genético aleatório, o qual, a seu ver, garante a simetria que deve existir entre todos os seres morais.

Com o debate proposto por Habermas, encontramo-nos no cenário contemporâneo, em que o antigo mito da criação é reinterpretado nos termos do assim alcunhado pós-humano, quando, supostamente, criador e criatura - num movimento inverso ao do Golem de Jeremias - imbricam-se num registro de submissão inte- 
gral aos aspectos mais imediatos e mecânicos de leis mal conhecidas (amiúde com o propósito de controlá-las), reprisando os equívocos do pecado original. Traduzindo no dialeto acadêmico atual, Sibilia (2002) denomina pós-orgânico o ser humano que, tendo se apropriado dos mecanismos de seleção natural e interferindo arbitrariamente em sua vida instintiva, estaria deixando de ser criatura para transformar-se em criador de si mesmo. Na 'evolução pós-orgânica' que a autora profetiza, transitando num ambiente em que artificialidade e natureza biológica se mesclam, abundam conseqüências imprevistas e catastróficas, com a clonagem em lugar de honra, em nicho mítico similar ao que abriga a expulsão do Paraíso, o Dilúvio e a Torre de Babel.

\section{Ciência e ética em prol da sabedoria}

Ao finalizar a introdução do livro sobre a clonagem, Atlan (Atlan et al., 1999b) remete ao mito de Prometeu. Lembra que, para vingar-se daquele que se dispusera a libertar os homens por meio da ciência e da técnica, Zeus enviara Pandora, uma bela mulher artificialmente criada. Insuflada por desígnio maldoso, coube a Pandora espalhar todos os males - doenças e querelas - que acabrunham a humanidade. Mas no fundo da caixa de Pandora existe a esperança, e embora ela possa tardar, acaba por escapar de seu invólucro. Essa é a posição de Atlan a respeito de todo o progresso tecnocientífico em geral e da clonagem em particular, que devem estar informados por uma crença- expressão de racionalidade mítica - confiante, em sintonia com um projeto de libertação do ser humano. Para Atlan, esse processo insere-se naquele de uma evolução mental humana em curso, conceito que, a nosso ver, pode ser caracterizado também como uma verdadeira 'revolução antropológica' (Schramm, 2003b).

O mito de Prometeu é bastante adequado para ilustrar a atitude interna recomendada por Atlan. Segundo Diel (1991), trata-se de mito de criação que "simboliza precisamente a história evolutiva do gênero humano" (p.232), em que o protagonista passa por conquistas audaciosas, desvios, estagnações e recuperações de energia. O autor sublinha várias analogias entre o mito grego de Prometeu e o mito judaico de Adão, pois ambos teriam como tema a história evolutiva da humanidade. No mito de Prometeu, as conseqüências da culpa original (o rapto do fogo) são apagadas com a ascensão final do personagem ao Olimpo, liberto de seu jugo por Hércules, o mais humano e entusiástico dos heróis. Na interpretação de Diel, Hércules é o antídoto da banalização que atara os membros de Prometeu à rocha da imobilidade, obrigando-o a ter seu fígado consumido pela águia, filha da vaidade e do remorso. Em relação ao mito bíblico, a versão cristã exigirá a intervenção de Cristo para que 
Adão seja redimido; nas versões de interpretações talmúdicas, a 'maldição bíblica' também deverá ser suspensa, porém através da 'atividade redentora' do exercício da sabedoria.

Atualmente outro mito sobrepõe-se ao de Prometeu: o de Dédalo. Atlan (2005) o comenta por meio de uma releitura do livro clássico de 1923, de John Haldane (1995). Dédalo, artífice por excelência, inventor das primeiras estátuas animadas e da cola, seria o primeiro homem moderno, no sentido em que sua técnica é amoral e não tem preocupação com os deuses - uma vez que, diferentemente de Prometeu, não é punido por eles. Com um artefato que permitiu à insaciável Pasífae ter relações sexuais com um touro, Dédalo colaborou com o nascimento do Minotauro, ser híbrido, dir-se-ia hoje uma 'quimera' (organismo constituído pela fusão muito precoce de células-ovo de diferentes espécies). Mas, como bem assinala Balandier (1999), também aqui o mito oferece a condição de superação da 'monstruosidade'. Teseu, o herói libertador, serve-se do fio de Ariadne e de uma coroa luminosa (que lhe fornece 'indícios') para se orientar no labirinto e vencer o embate com o Minotauro. Para Balandier (p.11), "hoje, o 'fio' é a razão crítica; e o 'indício', a intuição que leva à compreensão".

Assim, é uma desassombrada revisão dos mitos, parcial e convencionalmente digeridos, que Atlan propugna como remédio para a alma acabrunhada em virtude de sua pretensa sujeição ao 'potencial destrutivo' (mítico) da biotecnociência. Na verdade, ocorreria que, quando esta atesta a possibilidade concreta de direcionamentos existenciais inusuais, obriga a pôr em xeque aqueles decorrentes do hábito e ou da inércia intelectual e ética. Ou seja, não há conexão necessária entre quaisquer das possibilidades abertas pelos avanços biotecnológicos e suas utilizações, ou libertadoras ou deletérias.

Dessa ótica, uma ampla gama de mal-entendidos relativos à clonagem revela-se insignificante. Parece-nos pertinente uma associação das idéias de Atlan com as de Zizek (23 jun. 2003), que, valendo-se de uma outra convicção filosófica de ordem também determinista (marxista), chega a conclusões muito similares às de Atlan. Com efeito, Zizek critica a posição conservadora tanto de Fukuyama (2003) quanto de Habermas (2001), que, a pretexto de defesa da 'natureza humana' (assimilada a nosso 'patrimônio genético único'), partilham a tese de que nossa dignidade só pode ser mantida se conservarmos a indeterminação da disposição genética, isto é, se nos abstivermos de tentar controlar o núcleo de nossa personalidade por meio de manipulação biotecnológica. Ou seja, seria melhor saber pouco, para não ter acesso a qualquer dispositivo que permita alterações genéticas que possam se prestar a propósitos supostamente antiéticos e ou não-democráticos.

Zizek (23 jun. 2003) evidencia, antes de tudo, a impossibilidade de retorno a um 'imediato ingênuo', já que sabemos que nossas 
tendências naturais dependem da contingência genética. Agir como se não fosse o caso, além de falso, em última análise estaria limitando a nossa autonomia e liberdade de intervenção científica com base num argumento conservador, obscurantista, segundo o qual seria melhor 'escolher ignorar'. Com isso, evita-se enfrentar a verdadeira pergunta: "Como essas novas condições nos forçam a transformar e reinventar as próprias noções de liberdade, autonomia e responsabilidade ética?" (p.5).

Para Zizek (23 jun. 2003), a conclusão inevitável à qual a biogenética nos compele é a de que, na verdade, nunca tivemos o tipo de liberdade e de dignidade defendidas por Habermas. A valoração de quem sou depende menos de meus atributos naturais do que de como eu mesmo me posiciono a respeito, de forma simbólica e subjetiva. Assim, seriam superficiais as ilusões de que manipulações genéticas poderiam 'criar' uma elite 'mais inteligente', daí se tirando conseqüências éticas e infringindo-se, portanto, sem argumentos cogentes, a lei de Hume. Zizek reconfigura o problema:

Quando sabemos que meu 'talento natural' depende de uma substância química em meu cérebro, realmente importa, moralmente, se eu o obtive do exterior ou ao nascer? ... E se minha própria disposição para me dedicar ao esforço interior, à disciplina e ao trabalho duro depender de uma substância química? E se, para vencer um concurso, eu não tomar diretamente uma droga que reforce minha memória, mas 'simplesmente' uma droga que reforce meu empenho e dedicação? Também é 'trapaça'? (Zizek, 23 jun. 2003, p.6)

Hottois (2005) também critica o 'conservadorismo naturalista' de Fukuyama e Habermas, desfiando argumentos relativos à noção de temporalidade: nos dois autores essa concepção é vaga, faz-se projeção de decênios, apesar da grande imprevisibilidade do futuro - descobertas e invenções podem alterar completamente as condições atuais, assim como as energias e meios de comunicação disponíveis. Um exemplo paradigmático dos rumos inesperados que podem vir a nortear os progressos tecnológicos é o das pesquisas em embriões relacionadas à reprodução assistida. Procedimento desenvolvido a princípio como tratamento para infertilidade masculina - a análise genética dos estágios iniciais de um embrião, antes de sua transferência para um núcleo -, tornou-se o mecanismo-padrão usado por casais inférteis para facilitar a reprodução. A tecnologia, portanto, acompanhando os novos objetivos, transformou-se e continuará a fazê-lo, ampliando possibilidades reprodutivas e chegando a "gerar resultados sociais e culturais que não podemos prever com base nas informações que temos hoje. E essas conseqüências não só são imprevistas como imprevisíveis!" (Manifesto..., 
24 nov. 2002, p.8). Em compasso similar, a distinção e separação entre sexualidade e reprodução humana, impulsionadas vigorosamente pelo movimento feminista, vieram repercutir na possibilidade, dificilmente previsível à época, de tornar corriqueiro o método de reprodução assistida, evitando, assim, sofrimentos desnecessários e elevando consideravelmente o patamar de autonomia feminina.

Essa aposta nos aspectos positivos do que virá a aflorar no futuro leva uma vantagem ética inegável sobre as atitudes meramente prudenciais e de ignorância. Além disso, do ponto de vista lógico, o argumento 'implícito' de proibir algo em razão de seu possível mau uso é, de fato, um não-argumento, ou pelo menos muito pobre filosoficamente, pois acaba em um não agir que acarreta igualmente conseqüências, em termos de responsabilidade ética (Harris, 1998).

Embora vinculando-se a uma atitude mais cautelosa, na tentativa de controle das variáveis indesejáveis embutidas no futuro, o bioeticista John Harris recomenda uma postura ativa em face do que considera 'perigos infalíveis':

Se quisermos ter alguma chance de manter ou conseguir o controle de nosso destino, devemos tentar antecipar o que poderia acontecer, e estabelecer se temos que ficar satisfeitos ou insatisfeitos com os empecilhos em nosso caminho. [Pois os perigos futuros tendem a tornar-se] infalivelmente atuais e reais, e quando isso acontece, pode ser mais difícil controlá-los. [Isso] nos tornaria responsáveis por causar imensos sofrimentos evitáveis, [já que] não faz nenhum sentido acreditar que não fazer nada seja necessariamente uma escolha mais responsável do que fazer algo. (Harris, 1998, p.6)

Porém Kahn (2003) oferece-nos uma abordagem original em relação ao tão proclamado direito ao 'patrimônio genético', brandido pelos opositores da clonagem como demanda democrática. Antes, ao contrário, a defesa do 'patrimônio genético' pode estar a serviço da mais radical e biologizante manutenção do status quo. $\mathrm{O}$ geneticista francês alerta para o fato de que os últimos vinte anos se caracterizaram pela crescente intolerância a filhos não biológicos. Os custosos métodos de procriação assistida teriam progredido enormemente, impulsionados pela exigência imperiosa de filhos de sangue:

[a] rejeição da filiação afetiva ou por valores, propriamente humana, em favor da filiação por genes, se inscreve perfeitamente no duplo movimento fundamentalista, naturalista e sociobiológico que caracteriza nossas sociedades globalizadas, neste início de milênio ... Já que os genes governam mais ou menos diretamente as qualidades humanas, psíquicas e sociais, é ilusório querer separar da evolução do patrimônio genético a trans- 
missão de valores afetivos e intelectuais. A própria expressão 'patrimônio genético' indica uma chave possível da exigência moderna de que ele seja obrigatoriamente passado aos filhos. (Kahn, 2003, p.234-235)

Nesse contexto, a evolução inexorável das tecnociências aponta já o advento da ectogênese, isto é, do útero artificial, artefato intimamente ligado ao processo da clonagem, uma vez que a possibilidade técnica de clonar mamíferos depende da viabilidade técnica e da afirmação social da ectogênese (Lederberg, oct. 1966, citado em Atlan, 2005, p.80). A partir de então, poder-se-á esperar profundas alterações nas construções identitárias humanas, com modificações sociais e psicológicas radicais nas experiências de masculino e feminino e naquelas de família. Também o papel do Estado deverá ser reavaliado estruturalmente como instância responsável (ou não) por prover direitos mínimos de sobrevivência às crianças, filhas das novas tecnologias impessoais (Atlan, 2005).

Atlan (2005) aceita o útero artificial no mesmo registro que o da pílula anticoncepcional, ou seja, o de permitir à mulher o amplo direito de dispor de seu corpo. Já as reservas atlanianas quanto à clonagem reprodutiva estão, como vimos, circunscritas ao presente, logo são puramente circunstanciais (Atlan, 1999b). No panorama social e cultural de hoje, ainda podem ser identificadas as tendências humanas que nos permitem suspeitar que clones, pela já citada especificidade das condições em que foram gerados, poderiam ser tratados de uma maneira que se assemelhe ao racismo ou à escravidão. Mas pode-se imaginar um futuro possível em que não haja mais racismo nem a tendência a reduzir os outros à escravidão. Além disso, nem todo desejo de ter filhos obedece a imperativos psicológicos que possam ser considerados, de um ponto de vista mais profundo, libertadores para os indivíduos que nascem. Os próprios critérios de filiação e parentesco, acerbamente defendidos por antropólogos que fazem muitas restrições à clonagem, como Marc Augé (2003), podem ser revistos estruturalmente, levando em conta toda uma outra concepção de família e de laços de afeto entre indivíduos, diversos dos hoje por nós concebidos.

Atlan (1999b) argumenta que a fabricação de indivíduos através da reprodução assexuada pode ser avaliada pelo prisma da evolução da humanidade. Tratar-se-ia, sem dúvida, de uma modificação muito importante na natureza humana, mas não a primeira; tão relevantes quanto ela teriam sido a introdução da agricultura e a passagem da poligamia à monogamia. Para ele, "em todas as manipulações da procriação humana, há também um elemento de libertação" (p.57). Uma primeira revolução nesse sentido foi a pílula anticoncepcional, que permitiu o planejamento familiar, a se complementar, eventualmente, com a legalização do pleno direito da mu- 
lher ao aborto, como expressão de sua autonomia (Atlan, 1999a). A mulher também tem direito ao parto menos doloroso: "pode se ver o perfil, no horizonte, de uma libertação completa do fardo do parto ... ao menos para aquelas mulheres que o percebem comoum fardo...Emnome do que serecusará às mulheres odireito de dispor de seu corpoe de se libertar dos inconvenientes da gravidez?" (p.17-18). O autor é enfático nesse pormenor:

[se] se vinculam essas manipulações da procriação ao fim do trabalho ou à diminuição do tempo de trabalho, ou, em todo caso, do trabalho penoso, é ao fim da maldição bíblica que nós assistimos: trabalhar com o suor de seu rosto, dar à luz com dor, acabou! Para alguns, essa idéia corresponde a uma blasfêmia porque a maldição não deveria jamais ser suspensa; para outros, ao contrário, ela deve ser suspensa. Para mim, a maldição deve ser suspensa. (Atlan, 1999b, p.57)

A desvinculação do sexo de sua função biológica já constitui um dado cultural disseminado, uma vez que, na maioria das vezes, a atividade sexual visa intimidade afetiva e prazer sensual e não reprodução. Propagam-se diversos métodos para gerar bebês sem o ato físico do sexo, embora ainda a maior parte da reprodução derive desse ato. E como aponta Kurzweil (23 mar. 2003, p.4): “[apesar] de não ser aceita por todos os setores da sociedade, a desvinculação entre sexo e função biológica foi prontamente - pode-se dizer até 'ansiosamente' - adotada pela maioria".

Atlan vai às raízes desse sentimento. Para ele, deve-se chegar, brevemente, a uma "separação total entre procriação e sexualidade. As crianças serão produzidas desde o início - fecundação in vitro, clonagem - até o fim - por gestação artificial - fora do corpo das mulheres" (Atlan, 1999a, p.18). De forma completamente independente da sexualidade, as técnicas de reprodução, segundo seus objetivos, dividir-se-ão em dois grupos visando "prevenir gravidez e nascimentos indesejáveis [ou] permitir, ao contrário, gravidez e nascimentos de outra forma impossíveis" (Atlan, 2005, p.104). Pílulas e aborto seriam recursos do primeiro grupo e reprodução assistida e útero artificial, do segundo.

Portanto a fabricação do vivente - humano e não-humano acompanhará, de uma maneira que parece inevitável, a liberação da humanidade da maldição das condições que a forçam a sofrer, simplesmente para sobreviver, nutrindo-se e reproduzindo-se. A clonagem reprodutiva humana, ao que tudo indica, será apenas mais um passo nesse sentido (Atlan, 1999a, p.18).

\section{Considerações finais}

Em seu mais recente ensaio, Atlan (2005) se refere a um "novo Éden ou a um pesadelo dissipado" (p.168) - de forma alguma ga- 
rantido, evidentemente -, remetendo aos benefícios que as biotecnologias poderão trazer às novas relações entre homens e mulheres, inscrevendo-as "em uma evolução, com base na natureza humana terrena, obscura, em direção a uma sobrenatureza humana ígnea, ardendo ao calor e à luz do fogo, ech" (p.174) - alusão aqui ao ech yah, 'fogo divino' judeu, sinônimo de energia, inteligência e afetividade vibrantes. Assim, a ciência e a tecnologia vão dando condições para libertar gradualmente os filhos de Adão e Eva daquilo que têm há muito suportado - com maior ou menor grau de consciência - como efeitos de uma 'maldição bíblica', a inevitabilidade do trabalho penoso e do parto doloroso. Tal libertação prática, permitindo uma reformulação e ou transcendência dos mitos fundadores no tempo, facultaria à espécie humana o acesso à sua vocação mais profunda e elevada, a atividade criadora da sabedoria.

Mas para que isso ocorra deverão ser ainda desconstruídas algumas insistentes fantasias de ordem mítica - logo, muito poderosas, pois inscritas no registro que imprime significado a nossos pensamentos, emoções e atos. Com efeito, opõe-se constantemente conhecimento à vida, ou - nos termos deste debate - o crescente controle de variáveis genéticas facultado pela biotecnociência a uma experiência existencial feliz e livre. Em termos atlanianos, isso equivale a ignorar que a árvore do conhecimento e da vida é uma só, em sua origem. Porém associam-se ao 'pós-humano' ecos de um entendimento equivocado do 'além-humano' (übermenschlich) nietzschiano, no qual o convite ao indivíduo para vencer suas amarras 'demasiado humanas' é identificado à recusa de um pretenso 'humanismo'. Atlan (2002), entre outros, denuncia este último como freqüente pretexto para horrores como colonialismo e guerras, levados adiante em nome da imposição de 'valores humanos' reputados superiores (pelos vencedores). Se o termo humanismo perdeu boa parte de sua auréola artificial, o correlativo humanização se apresenta hodiernamente embebido de uma pieguice preocupante, já que está inserido na atmosfera contemporânea de fragilização dos indivíduos, diretamente relacionada, por sua vez, à ausência generalizada de projetos significativos para os grupos sociais onde aqueles se reconheçam (Lipovetsky, 2004). Nesse rastro, estimula-se uma 'cultura de terapia' (Furedi, 2003), posto que, numa sociedade movida pela moral do desejo soberano, o próprio apelo à solidariedade - com muitas e dolorosíssimas exceções perde qualquer força legítima de convicção e dilui-se numa ideologia de emocionalismo e ou vitimização improdutiva que mal mascara seu oportunismo midiático, a par de sua absoluta irrelevância ética.

Ao contrário - retomando a trilha atlaniana, à qual acrescentamos a tradição deleuziana de aproximar Espinosa a Nietzsche - o übermenschlich que se prenuncia seria a assunção plena e irrestrita 
da própria existência (cuja contraface é a assunção intuitiva de responsabilidade de cada um para com o outro), no seu nível mais alto de autonomia, com todos os riscos aí implicados. Tal tomada de posição acompanharia obrigatoriamente a experiência de afetos positivos, que aumenta a potência para ser e agir em indivíduos e grupos sociais e se expressa como alegria e felicidade. Uma vez que ontologia e epistemologia se entrelaçam na filosofia de Espinosa, o crescente conhecimento das causas constitui a racionalidade especificamente humana, sendo mobilizado, entretanto, pelas vicissitudes de um corpo fremente de paixões (positivas), inclusive aquelas que impelem à sabedoria. Lembremos que, para Espinosa, o indivíduo e a 'multitude' são duas manifestações inextricáveis da condição humana no mundo (Matheron, 1988), o que comunica imediata dimensão democrática ao projeto espinosista/atlaniano. Esgarça-se, pois, a imagem estereotipada do cientista-filósofo elitista, enrijecido e indiferente, desencarnado da vibração irrenunciável da afetividade e da sensibilidade humanas. Aliás, um dos pressupostos mínimos estabelecidos por Atlan para alcance desse novo patamar é de natureza moral: "uma compaixão 'maternal' desinteressada, uma atenção cuidadosa para com o outro e para com a justiça deverão impregnar as relações humanas, sejam quais forem as formas de organização familiar, econômica, ideológica ou política que tomarão as sociedades futuras" (Atlan, 2005, p.177).

Livres, enfim, da superstição, das peias do medo e das expectativas (Spinoza, 1965, Prefácio), homens e mulheres poderão aproveitar os benefícios concretos, de extensão ainda imprevisível em sua existência cotidiana, oriundos da pesquisa biotecnocientífica, a par daqueles propiciados por sua privilegiada condição - racional e afetiva - de acesso à sabedoria.

\section{BIBLIOGRAFIA}

Aleksandrowicz, Ana Maria C. 2002

Atlan, Henri 2005

Atlan, Henri 2003

Atlan, Henri 2002

Atlan, Henri 1999 a

Atlan, Henri $1999 \mathrm{~b}$
Complexidade e metodologia: um refinado retorno às fronteiras do conhecimento. In: Minayo, Maria Cecília S.; Deslandes, Suely F. (Org.). Caminhos do pensamento: epistemologia e método. Rio de Janeiro: Editora Fiocruz. p.49-79.

L'utérus artificiel.

Paris: Seuil.

Les étincelles de hasard, tome II : athéisme de l’Écriture. Paris: Seuil.

La science est-elle inhumaine?: essai sur la libre nécessité. Paris: Bayard.

Les étincelles de hasard, tome I: connaissance spermatique. Paris: Seuil.

Possibilités biologiques, impossibilités sociales. In: Atlan, Henri et al. (Org.). Le clonage humain. Paris: Seuil. p.17-41. 


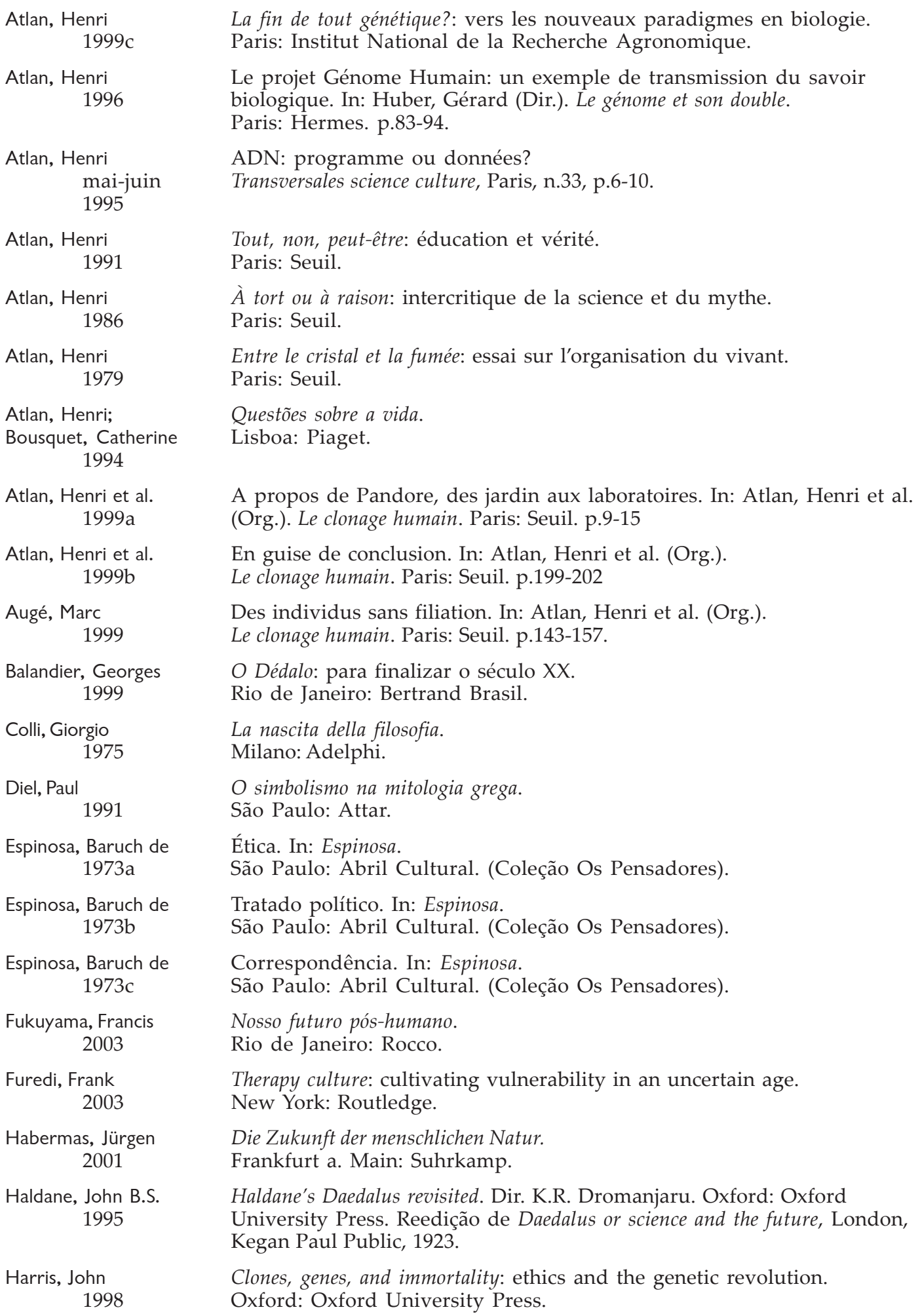




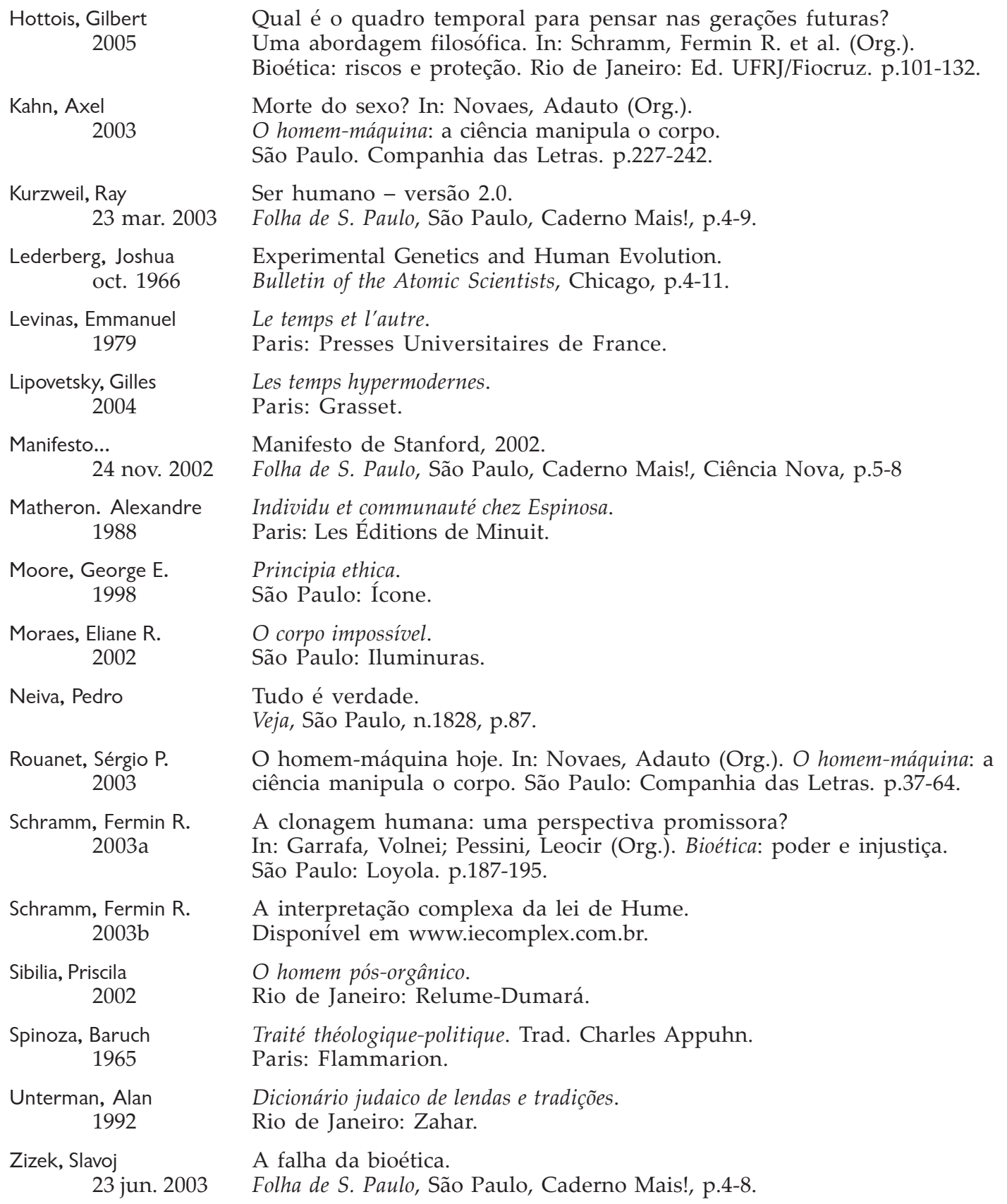

